\title{
KEMAMPUAN KOGNITIF DALAM MENINGKATKAN EFEKTIVITAS \\ PEMBELAJARAN ILMU SOSIAL BAGI SISWA SEKOLAH DASAR
}

\section{COGNITIVE ABILITY IN IMPROVING THE EFFECTIVENESS OF SOCIAL LEARNING FOR ELEMENTARY SCHOOL STUDENTS}

\author{
Hasan Basri \\ Madrasah Aliyah Negeri Purwakarta, Purwakarta, Indonesia \\ hsnbsri76@gmail.com
}

\begin{abstract}
ABSTRAK
Kemampuan kognitif adalah keterampilan berbasis otak yang diperlukan untuk melakukan tugas apapun dari yang sederhana hingga yang paling kompleks. Struktur kognitif yang ada pada seorang anak sangat cepat, seperti: mereka akan lebih cepat menangkap dan mengingat sesuatu yang nyata baginya. Penelitian ini bertujuan untuk mengkaji tentang kemampuan kognitif dalam meningkatkan efektivtas pembelajaran ilmu sosial. Penelitian ini menggunakan metode penelitian kualitatif yang ditujukan pada pembelajaran Ilmu Sosial pada tingkat Sekolah Dasar. Instrumen pengumpulan data dalam penelitian ini menggunakan observasi, wawancara studi dokumentasi, kemudian dianalisis dengan teknik induktif. Hasil penelitian menunjukan bahwa Peaget membagi perkembangan kognitif menjadi empat fase yaitu fase sensorimotor, fase pra-operasional, fase operasi beton, dan fase operasi formal. Strategi untuk setiap fase adalah dengan menggunakan tindakan dan instruksi yang tepat dari guru. Dari hasil penelitian dapat disimpulkan bahwa teori kognitif Piaget telah menyumbangkan tema berkaitan dengan perkembanngan kognitif seseorang dan dapat menjadi acuan dalam meningatkan efektifitas pembelajaran Ilmu Sosial. Peneliti merekomendasikan pada penelitian selanjutnya untuk mengkaji tahap-tahap perkembangan kognitif yang mempengaruhi kegiatan belajar anak di sekolah maupun di rumah.
\end{abstract}

Kata kunci: kemampuan kognitif, perkembangan kognitif, dan pembelajaran ilmu sosial

\section{ABSTRACT}

Cognitive abilities are brain-based skills that we need to carry out any task from the simplest to the most complex. Cognitive structure that in all children very quickly such as they will more quickly to capture and remember something obvious to him. This research aims to describe the cognitive abilities in improving social science learning. This research uses qualitative research methods aimed at learning Social Science at elementary school. Instrument of data collection in this research use observation, interview study of documentation, then analyzed by inductive technique. The results showed that Peaget divided the cognitive development into four phases: sensorimotor phase, pre-operative phase, concrete operation phase, and formal operation phase. The strategy for each phase is to use right actions and instructions from the teacher. From the results of this resarch can be concluded that Piaget's cognitive theories have contributed to the theme related to cognitive development and can be a reference in improving the effectiveness of Social Science learning. Researchers recommend in next research to examine the stages of cognitive development that affect children's learning activities at school and at home.

Keywords: cognitive ability, cognitive development, and social science learning 


\section{PENDAHULUAN}

Perkembangan merupakan suatu proses perubahan fungsional yang bertahap dan bersifat kualitatif yang dialami individu menuju tingkat kedewasaan (Abidin, 2009) baik pada aspek fisik, kognitif, afektif, minat, bahasa maupun sosial (Muslikah, 2018). Banyak faktor yang turut berpengaruh dan saling terjalin dalam proses perkembangan ini, baik yang dikategorikan pada unsur-unsur bawaan maupun unsur-unsur pengalaman yang diperoleh dalam berinteraksi dengan lingkungan.

Aspek kognitif anak Sekolah Dasar merupakan salah satu aspek psikologis yang sangat perlu dipahami dan dihayati oleh seorang pendidik karena hakikat pembelajaran yang diselenggarakan pendidik harus disesuaikan dengan tingkat perkembangan kognitif anak. Sistem kognitif itu sendiri adalah perangkat pengolah yang kompleks pada manusia yang mampu memperoleh, melestarikan, memproses dan mentransmisikan informasi (Darouich dkk, 2017).

Perkembangan kognitif berfokus pada keterampilan berpikir, termasuk belajar, pemecahan masalah, rasional, dan mengingat. Perkembangan keterampilan kognitif berhubungan secara langsung dengan perkembangan keterampilan lainnya, termasuk komunikasi, motorik, sosial, emosi, dan keterampilan adaptif. Dengan kata lain kemampuan kognisi individu akan meningkat secara bertahap sejak lahir melalui interaksi anak dengan lingkungannya (Darouich dkk, 2017).

Siswa merupakan objek yang berkaitan langsung dengan proses pembelajaran, sehingga perkembangan kognitif sangat menentukan keberhasilan siswa di sekolah. Sebagaimana menurut Zainiyati (2017) bahwa sejak awal taksonomi koginitif pada tujuan pendidikan dirancang untuk memudahkan proses perancangan evaluasi pembelajaran.

Pada masa anak, peningkatan perkembangan kognitif sangatlah cepat, dimana anak lebih cepat menangkap dan mengingat sesuatu yang terlihat jelas baginya. Struktur kognitif umum yang memengaruhi semua pemikiran anak merupakan tahap perwakilan pemahaman anak tentang realitas pada masa itu. Anak biasanya berperan aktif dalam perkembangan diri mereka sendiri, dimana mereka mencari pengalaman baru dan mencoba untuk memahami apa yang mereka lihat dan dengar, dan bekerja secara aktif untuk memahami perbedaan antara informasi baru dan apa yang sebelumnya mereka yakini benar. Namun pada pembelajaran ilmu sosial, anak mengalami hambatan dalam menangkap pelajarannya. Hal ini karena pelajaran ilmu sosial merupakan sebuah pelajaran yang abstrak yang belum dapat dipahami oleh anak.Padalahal Berdasarkan model arsitektur kognitif yang mendasari fenomena pembelajaran (Atkitson \& Shiffrin, 1968) bahwa kemampuan kognisi dapat didefinisikan sebagai pemerolehan dan penginterpretasian informasi untuk jangka pendek (Darouich dkk, 2017) dan pada jangka panjang dapat dilihat sebagai fungsi adaptif dari manusia ke lingkungan budaya, sosial dan emosional (Anderson, 1994).

Berdasarkan latar belakang masalah tersebut, peneliti tertarik untuk mengkaji tentang kemampuan kognitif dalam 
meningkatkan pembelajaran ilmu sosial. Adapun tujuan penelitian ini adalah untuk mendekskripsikan tentang kemampuan kognitif siswa dalam meningkatkan efektifitas pembelajaran ilmu sosial bagi siswa sekolah dasar.

\section{METODE PENELITIAN}

Penelitian ini mengunakan metode penelitian kualitatif sebagaimana yang diungkapkan Bogdan dan Taylor (1992) sebagai prosedur penelitian yang menghasilkan data deskriptif berupa kata-kata tertulis atau lisan dari orang-orang dan perilaku yang dapat diamati. Penelitian iniditujukan pada pembelajaran Ilmu Sosial pada tingkat Sekolah Dasar. Instrumen pengumpulan data dalam penelitian ini menggunakan observasi, wawancara studi dokumentasi. Kemudian data yang telah diperoleh, dianalisis dengan teknik induktif.

\section{HASIL DAN PEMBAHASAN}

Menurtu Suntrock (2011), perkembangan manusia merupakan pola perubahan dimulai sejak pembuahan dan berlangsung terus sepanjang hidup melalui proses-proses biologis, kognitif, dan sosioemosi. Proses bilogis menghasilkan perubahan yang berkaitan dengan sifat dasar fisik individu. Proses kognitif merujuk pada perubahan pemikiran, inteligensi, dan bahasa dari individu. Sedangkan proses sosioemosi mencakup perubahan dalam relasi individu dengan orang lain, perubahan emosi, dan perubahan kepribadian. Ketiga proses perubahan ini saling mempengaruhi satu sama lain dan menghasilkan periode-periode dalam masa hidupnya.
Perkembangan kognitif sendiri adalah proses yang terjadi secara internal di dalam pusat susunan syaraf pada waktu manusia sedang berpikir (Ibda, 2015) dan berkembang secara bertahap sejalan dengan perkembangan fisik dan syaraf-syaraf yang berada di pusat susunan syarafmelalui interaksi anak dengan lingkungannya (Darouich dkk, 2017). Salah satu teori yang berpengaruh dalam menjelaskan perkembangan kognitif ini adalah teori Piaget.

Jean Piaget yang hidup dari tahun 1896 sampai tahun 1980 adalah seorang ahli biologi dan psikologi berkebangsaan Swiss. Ia merupakan salah seorang yang merumuskan teori yang dapat menjelaskan fase-fase perkembangan kognitif. Menurut Peaget (1952) teori perkembangan kognitif mengemukakanasumsitentangperkembangan cara berpikir individu dalam kompleksitas perubahannnya melalui per-kembangan neurologis dan pengalaman lingkungan. Oleh karena itu, berdasarkan definisi tersebut teori ini dibangun berdasarkan dua sudut pandang yang disebut sudut pandang aliran struktural (structuralism) dan aliran konstruktif (constructivism). Aliran struktural yang mewarnai teori Piaget dapat dilihat dari pandangannya tentang inteligensi yang berkembang melalui serangkaian tahap perkembangan yang ditandai oleh perkembangan kualitas struktur kognitif. Aliran konstruktif terlihat dari pandangan Piaget yang menyatakan bahwa, anak membangun kemampuan kognitif melalui interaksinya dengan dunia di sekitarnya.

Aspek kognitif menjadi hal utama dalam perkembangan manusia sebab keberhasilan dalam mengembangkan aspek kognitif dapat 
menentukan keberhasilan dalam aspek-aspek lainnya. Menurut Santrock (2007) proses perkembangan merupakan suatu proses yang bersifat kumulatif. Dengan demikian, perkembangan (kognitif) terdahulu akan menjadi dasar bagi perkembangan selanjutnya. Begitu pula sebaliknya, apabila terjadi hambatan pada perkembangan terdahulu maka perkembangan selanjutnya akan mengalami hambatan.

Adapun tahap perkembangan kognitif yang dimaksud adalah sebagai berikut:

1. Tahap Sensorimotor

Usia anak dari lahir hingga sekitar 2 tahun, merupakan tahap pertama menurut Piaget. Dalam tahap ini, bayi membangun pemahaman mengenai dunianya dengan mengkoordinasikan pengalaman-pengalaman sensoris dengan tindakan-tindakan fisik dan motorik. Bayi lahir dengan sejumlah refleks bawaan selain juga dorongan untuk mengeksplorasi dunianya. Skema awalnya dibentuk melalui diferensiasi refleks bawaan tersebut.

Pada tingkat ini, anak belum memiliki kemampuan intelektual yang cukup kompeten untuk memproses informasi dari dan melalui symbol-simbol dan kata-kata. Anak mengenali lingkungan sebatas apa yang sedang ada di depan mata mereka dan bukan yang sudah pernah mereka lihat. Bayi belum memiliki pengertian bahwa orang atau benda lain itu tetap ada meskipun tidak sedang berada di depan matanya. Bagi mereka, halhal lain di luar batas penglihatan tidak akan disadari, dan dapat dikatakan tidak ada.

Menurut Suparno (2001), mekanisme perkembangansensorimotorinimenggunakan proses asimilasi dan akomodasi. Tahap-tahap perkembangan kognitif anak dikembangkan dengan perlahan-lahan melalui proses asimilasi dan akomodasi terhadap skemaskema anak karena adanya masukan, rangsangan, atau kontak dengan pengalaman dan situasi yang baru.

\section{Tahap Praoperasional}

Berlangsung usia 2 hingga 7 tahun, merupakan tahap kedua menurut Piaget. Dalam tahap ini, anak mulai merepresentasikan dunia dengan kata-kata dan gambar-gambar, melampaui hubungan sederhana antara informasi sensoris dan tindakan fisik. Mereka membantuk konsep yang stabil dan mulai bernalar.

Pemikiran praoperasional adalah awal dari kemampuan melakukan rekonstruksi dalam pikiran terhadap hal-hal yang telah dicapai dalam bentuk perilaku. Pemikiran simbolik pada tahap ini sudah melampaui sekedar koneksi sederhana dari informasi sensori dan gerakan fisik. Konsep yang stabil mulai terbentuk, mental reasoning mulai tampak, terjadi egosentrisme dan magicalbelief atau kepercayaan benda mati itu hidup mulai terbangun. Terdapat dua sub tahapan pada pra-operasional.

Sub tahap fungsi simbolik merupakan sub tahapan pertama yang muncul pada usia 2 sampai 4 tahun. pada sub tahapan ini, anak mulai membangun kemampuan untuk menghadirkan secara mental objek yang tidak ada atau tidak nampak oleh mereka. Meskipun pada fase ini anak mencapai perbedaan yang jelas dibanding fase sebelumnya, pikiran mereka masih terdapat batas yakni egocentrism dan animism.

Egosentrism atau egosentris merupakan ketidakmampuan anak untuk membedakan 
sudut pandang dirinya dengan sudut pandang orang lain. Sedangkan animism atau animism merupakan keyakinan bahwa benda-benda mati memiliki kualitas yang seolah-olah hidup dan mampu beraksi (Santrock, 2007).

Sub tahap berfikir intuitif merupakan sub tahapan kedua dari tahap pra-operasional yang terjadi kira-kira 4 sampai 7 tahun. pada sub tahapan ini, seorang anak mulai menggunakan 'primitive reasoning' dan ingin mengetahui jawaban dari berbagai macam pertanyaan-pertanyaan yang mereka ajukan.

Piaget menamakan sub tahapan ini 'intuitif' karena anak terlihat sangat yakin tentang pengetahuan dan pemahaman yang dimilikinya. Mereka mengetahui sesuatu tanpa enggunakan pemikiran rasional.

\section{Tahap Operasional Konkret}

Berlangsung usia 7 hingga 11 tahun, merupakan tahap ketiga menurut Piaget. Dalam tahap ini, anak dapat melakukan operasi yang melibatkan objek-objek dan juga dpat bernalar secara logis, sejauh ha itu diterapkan dengan contoh-contoh yang spesifik atau konkret.

Pemikiran operasional konkret mencakup penggunaan operasi. Penalaran logika menggantikan penalaran intuitif, tetapi hanya dalam situasi konkret. Kemampuan untuk menggolongkan sudah ada, tapi belum bisa memecahkan problem-problem abstrak (Santrock, 2007). Operasi-operasi konkret memungkinkan anak memikirkan beberapa karakteristik dan bukan berfokus pada suatu properti tunggal suatu obyek. Salah satu keterampilan yang penting adalah kemampuan mengklasifikasikan atau membagi benda-benda ke dalam perangkatperangkat atau sub perangkat yang berbeda dan memperhitungkan keterkaitannya.

Anak sudah dapat berpikir secara lebih menyeluruh dengan melihat banyak unsur dalam waktu yang sama (decentering). Pemikiran anak dalam banyak hal sudah lebih teratur dan terarah karena sudah dapat berpikir seriasi, klasifikasi dengan lebih baik, bahkan mengambil kesimpulan secara probabilistis. Probabilitas ini merupakan sebagai suatu perbandingan antara hal yang terjadi dengan kasus-kasus yang mungkin mulai terbentuk. Tetapi sistem kombinasi baru ini muncul pada umur 11 atau 12 tahun. Konsep akan bilangan, waktu, dan ruang juga sudah semakin lengkap terbentuk. Ini semua membuat anak sudah tidak lagi egosentris dalam pemikirannya.

Meskipun demikian, pemikiran yang logis dengan segala unsurnya di atas masih terbatas diterapkan pada benda-benda yang konkret, pemikiran itu belum diterapkan pada kalimat verbal, hipotetis, dan abstrak. Maka, anak pada tahap ini masih tetap kesulitan untuk memecahkan persoalan yang mempunyai segi dan variabel terlalu banyak. Ia juga masih belum dapat memecahkan persoalan yang abstrak. Itulah sebabnya, ilmu aljabar atau persamaan tersamar pasti akan sulit baginya (Suparno, 2001).

\section{Tahap Operasional Formal}

Berlangsung usia 11 hingga 15 tahun dan terus berlangsung hinga masa dewasa. Ini merupakan tahap keempat dan terakhir menurut Piaget. Dalam tahap ini, individu melampaui pengalaman-pengalaman konkret dan berpikir secara abstrak dan logis. 
Sebagai bagian dari pemikiran yang abstrak, remaja mengembangkan gambaran keadaan yang ideal. Dampak dari berpikir yang lebih abstrak, remaja mulai mengembangkan gambaran keadaan ideal menurut dirinya. Dalam menyelesaikan masalah, pada tahapan ini remaja lebih sistematis dan menggunakan alasan logis.

Unsur pokok pada pemikiran formaladalah pemikiran deduktif, induktif, dan abstraktif. Yang pertama, mengambil kesimpulan khusus dari pengalaman yang umum. Yang kedua, mengambil kesimpulan umum dari pengalaman-pengalaman yang khusus. Dan yang terakhir, abstraksi tidak langsung dari objek. Pada tahap perkembangan ini, seorang remaja sudah mulai maju dalam memahami konsep proporsi dengan baik, sudah mampu menggunakan kombinasi dalam pemikirannya, dan sudah dapat menggabungkan dua referensi pemikiran. Ia juga sudah mengerti probabilitas dengan unsur kombinasi dan permutasinya (Suparno, 2001).

Adanya proses-proses pembentukan pengetahuan pada kognitif tersebut, maka setiap anakakan mengalami kemajuan dalam aspek kognitif. Perkembangan pikiran ini berlangsung secara alami dari lahir sampai dewasa, sehingga dapat diketahui perkembangan kognitif anak, yakni meliputi kemajuan kemampuan dalam pemikiran, pemecahan masalah, inteligensi dan bahasa individu. Sehingga Piaget menjelaskan (Desmita, 2009) bagaimana anak itu beradaptasi dengan menginterpretasikan objek dan kejadian-kejadian disekitarnya, bagaimana anak mempelajari ciri-ciri dan fungsi dari objek, bagaimana cara anak belajar mengelompokkan objek-objek untuk mengetahui persamaan dan perbedaan, maupun untuk membentuk perkiraan tentang objek dan peristiwa tersebut. Dalam hal ini anak belajar mengenal hal-hal yang abstrak menuju hal yang konkrit.

Berbagai cara dan teknik pembelajaran dikaji untuk memungkinkan konsep-konsep abstrak itu dipahami anak. Pada dasarnya definisi dan konsep belajar itu selalu menunjukkan kepada suatu proses perubahan perilaku atau pribadi seseorang berdasarkan praktik atau pengalaman tertentu (Makmun, 2012). Pemecahan berbentuk "jembatan bailey" untuk mengkongkritkan yang abstrak itu dengan enactive, iconic, dan symbolic melalui percontohan dengan gerak tubuh, gambar, bagan, peta, grafik, lambang, keterangan lanjut, atau elaborasi dalam kata-kata yang dapat dipahami siswa. Itulah sebabnya pembelajaran ilmu sosial seperti sejarah ataupun IPS pada siswa sekolah dasar bergerak dari yang kongkrit ke yang abstrak dengan mengikuti pola pendekatan lingkungan yang semakin meluas (expanding environment approach) dan pendekatan spiral dengan memulai dari yang mudah kepada yang sukar, dari yang sempit menjadi lebih luas, dari yang dekat ke yang jauh, dan seterusnya.

Menurut penelitian Hinde \& Nancy(2007) pengembangan ilmu sosial anak dilakukan dengan belajar sejarah dari salah satu kerangka kerja kurikuler oleh guru dengan menggunakan praktek-praktek yang sesuai dengan tahapan perkembangan. Pada tahap praoperasional, guru menggunakan tindakan dan instruksi lisan (strategi pengajaran tingkat yang lebih rendah). Mengajar 
dalam tahap operasi konkrit dan formal ini memerlukan strategi pengajaran-tingkat yang lebih tinggi. Sebagai contoh, strategi operasi konkrit melibatkan tangan untuk belajar, melakukan eksperimen dan pengujian benda saat mengajar, dalam tahap operasi formal memberikan kepada siswa kesempatan untuk memajukan keterampilan mereka dalam penalaran ilmiah dan pemecahan masalah dengan pertanyaan terbuka, serta mengeksplorasi kemungkinan hipotetis.

Dalam tujuan penelitian adalah untuk mengetahui efektivitas penyelidikan pembelajaran berbasis pada kinerja siswa dalam ilmu pengetahuan, menjelaskan bahwapembelajaran berbasis pada kinerja merupakan salah satu metode pembelajaran bagi siswa yang perkembangan kognitif mereka belum dapat berfikir abstrak. Oleh karena itu, pembelajaran ilmu sosial bagi anak juga dapat dilakukan dengan menggunakan metode dan/atau teknik bermain yang diterapkan di kelas dengan dihubungkan pada materi-materi ilmu sosial yang diajarkan. Andriana (2011) menjelaskan bahwa teknik merupakan penerapan sistematis dari sekumpulan prinsip belajar terhadap suatu kondisi atau tingkah laku yang dianggap menyimpang, dengan tujuan melakukan perubahan. Perubahan yang dimaksud bisa berarti menghilangkan, mengurangi, meningkatkan, atau memodifikasi suatu kondisi atau tingkah laku tertentu demi tercapainya tujuan pembelajaran.

Menurut Susanto (2011) dunia anak adalah dunia bermain. Oleh karena itu, wajar saja jika dalam aktivitas mereka sehari-hari lebih banyak bermaindi banding belajar. Tetapi sebenarnya, pada proses bermain itulah mereka belajar, karena pada setiap permainan anak ada cara atau peraturan yang sudah menjadi ketentuan, berlaku pola hukum penghargaan dan sanksi, ada pemenang ada yang kalah, dan semua berada pada posisi proses berlatih menuju puncak prestasi yang menuntut siswa besikap sportif dan komitmen terhadap aturan main.

Hal ini membantu perkembangan anak tidak hanya mengetahui isi pembelajaran mengenai ilmu sosial, namun juga mengasah perkembangan kognitif anak menjadi lebih kreatif serta mandiri.

\section{SIMPULAN}

Teori kognitif Piaget telah menyumbangkan tema berkaitan dengan perkembanngan kognitif seseorang dari lahir hingga dewasa dan dapat menjadi acuan dalam meningatkan efektifitas pembelajaran Ilmu Sosial dengan strategi yang tepat pada setiap fase perkembangan melalui tindakan dan instruksi yang tepat dari seorang guru. Untuk selanjutnya pengembangan penelitian ini bisa dilakukan dengan mengkaji tahap-tahap perkembangan kognitif yang mempengaruhi kegiatan belajar anak di sekolah maupun di rumah. Adapun implikasi teori kognitif anak dalam praktek bimbingan dan konseling yaitu aktivitas di dalam proses belajarmengajar hendaknya ditekankan pada pengembangan struktur kognitif melalui pemberian kesempatan pada anak untuk memperoleh pengalaman langsung dalam berbagai aktivitas pembelajaran yang sesuai dengan pembelajaran terpadu dan mengandung makna, memulai kegiatan dengan membuat konflik dalam pikiran anak. Misalnya, memberikan jawaban yang 
salah untuk memotivasi anak memikirkan dan mengemukakan jawaban yang benar, memberi kesempatan pada anak untuk melakukan berbagai kegiatan yang dapat mengembangkan kemampuan kognitifnya. Misalnya, mengubah objek-objek yang

\section{DAFTAR RUJUKAN}

Abidin, Y. (2009). Guru dan Pembelajaran Bermutu. Bandung: Rizqi Press.

Anderson, J. R. (1994). Learning and Memory: An Integrated Approach. Journal of Developmental \& Behavioral Pediatrics, 17(2), hlm. 125-126.

Andriana, D. (2011). Tumbuh Kembang dan Terapi Bermain pada Anak. Jakarta: Salemba Merdeka.

Atkinson R.C.,\& Shiffrin R.M. (1968). Human memory: A proposed system and its control processes. New York: Academic Press.

Bogdan, R., \&Taylor. (1992). Pengantar Metode Penelitian Kualitatif. diterjemahan oleh Arief Rurchan. Surabaya: Usaha Nasional.

Darouich, A., Khoukhi, F.,\& Douzi, K. (2017). Modelization of cognition, activity and motivation as indicatorsfor Interactive Learning Environment. Advances in Science, Technology and Engineering Systems Journal, 2 (3), hlm. 520-531.

Desmita. (2010). Psikologi Perkembangan Peserta Didik. Bandung:Remaja Rosdakarya.

Hinde, E. R., \&Nancy. (2007). Elementary Teachers' Application of Jean Piaget's Theories of Cognitive Development during Social Studies Curriculum Debates in Arizona. The Elementary School Journal Vol. 108, No.1.

Hurlock, E. B. (1980). Psikologi Perkembanngan Suatu Pendekatan Sepanjang Rentang Kehidupan. Jakarta: Erlangga.

Ibda, F. (2015). Perkembangan Kognitif: Teori Jean Piaget. Intelektual. 3 (1). Hlm. 28-38.

Makmun, A.S. (2012). Psikologi Pendidikan Perangkat Sistem Pangajara Modul. Bandung: Remaja Rosdakarya.

Muslikah, M. (2018). Perkembangan Individu [online]. Diakses dari https://www.researchgate. net/publication/323028558.

Piaget, J. (1952), The Origins of Intelligence in Children.New York: International Universities Press.

Santrock, J. W. (2007). Child Development Eleventh Edition. Singapore: McGraw Hill International Editions.

Santrock, J. W. (2007). Psikologi Pendidikan, Terj. Tri Wibowo B.S., Jakarta: Kencana.

Suparno, P. (2001). Teori Perkembangan Kognitif Jean Piaget. Yogyakarta: Kanisius.

Susanto, A. (2011). Perkembangan Anak Usia Dini Pengantar dalam Berbagai Aspeknya. Jakarta: Kencana Prenada Media Group.

Thompson, C. L.,\& Henderson, D. A. (2007). Counseling Children, Seventh Edition. Belmont: Thomson. 
Yusuf, S.,\& Juntika,N. (2012). Landasan Bimbingan \& Konseling. Bandung: Remaja Rosdakary.

Zainiyati, H.S. (2017). Understanding the Cognition Process of the Students Using the Internet as a Learning Resource. Jurnal Pendidikan Islam, 3 (1), hlm: 57-6. 